\title{
Spectral displacement (SD) of banda aceh's soft soil for seismic vulnerability assessment
}

\author{
Taufiq Saidi ${ }^{1}$, Teuku Budi Aulia ${ }^{1}$, Bambang Setiawan ${ }^{2}$, Nora Abdullah $^{1, *}$, and Muttaqin Hasan ${ }^{1}$ \\ ${ }^{1}$ Syiah Kuala University, Faculty of Engineering, Department of Civil Engineering, 23111 Banda Aceh, Indonesia \\ ${ }^{2}$ Syiah Kuala University, Faculty of Engineering, Program Study of Geological Engineering, 23111 Banda Aceh, Indonesia
}

\begin{abstract}
Reliable spectral displacement (SD) in a wide range of response periods is crucial in seismic vulnerability assessment for Banda Aceh-Indonesia as the city is founded on a thick-soft soil. This SD is excellent for estimating building drift ratio from which the vulnerability of building is assessed. SD can be obtained from conversion of the acceleration spectra (converted SD) and site response analysis (analyzed SD). In this paper, both converted- and analysed-SDs are developed for Banda Aceh's soft soil case using three historical seismic events of the 2012 Simeulue II, the 2013 Mane-Geumpang, and the 2013 Bener Meriah earthquakes and three soil models from which acceleration-displacement response spectrum (ADRS) of Banda Aceh's soft soil is proposed. This proposed ADRS is compared to the generic response spectra of Centre of Research and Development of Housing and Settlement (PUSKIM) Indonesia. It can be concluded that the Proposed ADRSs can be used as another source in determining the performance of a building beside the PUSKIM ADRSs. Furthermore, the developed SDs were used to calculate the drift of 2-, 3-, and 4-storey typical shop-house buildings at Banda Aceh-Indonesia.
\end{abstract}

\section{Introduction}

The city of Banda Aceh-Indonesia is founded on thick alluvium (soft soil) [1]. The city was hit by the mega earthquake in 2004 which caused severe damages to reinforced concrete (RC) buildings as shown in Figure 1 [2]. Estimated response spectral acceleration up to $0.8 \mathrm{~g}$ was suggested by [3]. One of contributing factors to the damages can be an improper structural design of the affected buildings. This improper design causes the building performance capacity less than the forcedemand (seismic loading). Currently, the development in engineering knowledge allows an engineer to evaluate the performance of the building due to dynamic loading which is well known as performance-based engineering (PBE) method.

The performance of buildings is defined from the capacity spectrum (output of inelastic analysis) and seismic demand, i.e., ground motion spectrum (Figure 2) $[4,5]$. Many researchers around the world have successfully applied this PBE (see [6-8]). This PBE requires spectral displacement (SD), in addition to the standard input in terms of spectral acceleration (SA). Furthermore, a better understanding of local characteristics is essential for successful engineering application [9-11]. Therefore, in Banda Aceh case, the spectral displacement and drift are estimated.

This study estimates SD and drift of Banda Aceh case based on three historical earthquake events and three sub-surface models. The events are estimated at the Richter local magnitudes (ML) of 8.1, 6.0 and 6.2 for the
2012 Simeulue II, 2013 Mane-Geumpang and 2013 Bener Meriah earthquakes, respectively. Three subsurface models are distributed across the Banda Aceh's soft soil. Site response analyses were carried out. The results were used to calculate both SD and drift of structure founded on Banda Aceh's soils. Accelerationdisplacement response spectrum (ADRS) is proposed and compared to Indonesian generic response spectra of Centre of Research and Development of Housing and Settlement (PUSKIM) Indonesia [12].

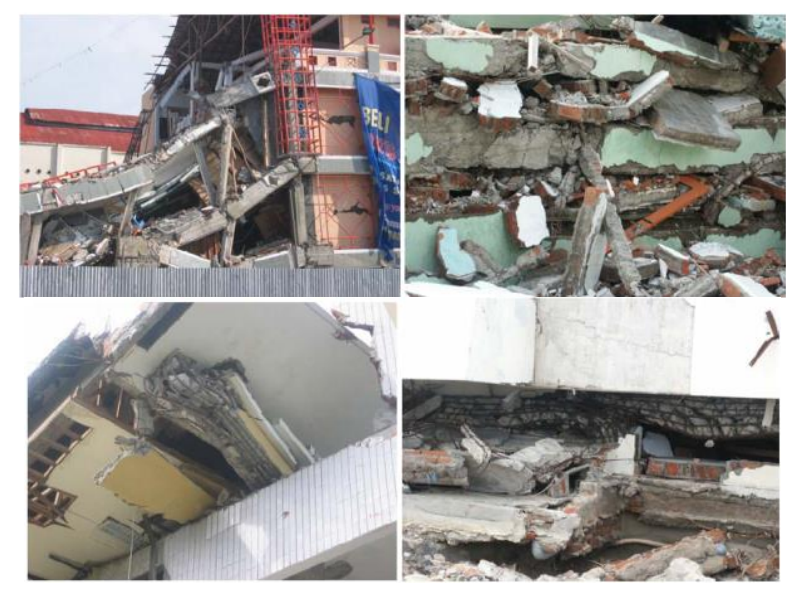

Fig. 1. 2004 mega earthquake damages at Banda Aceh [2].

\footnotetext{
* Corresponding author: nora.abdullah@unsyiah.ac.id
} 


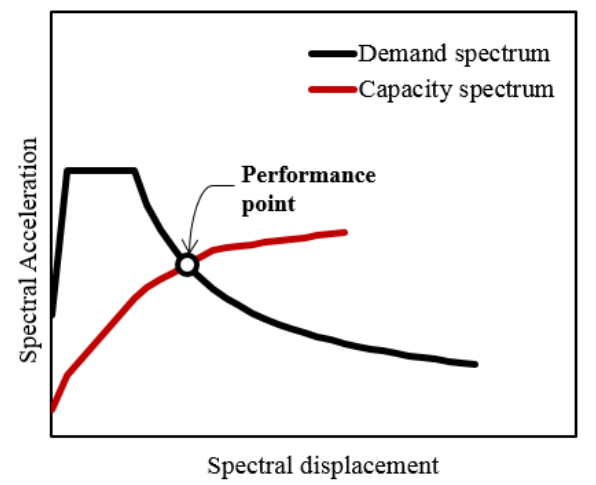

Fig. 2. The performance point where capacity and demand are equal $[4,5]$.

\section{Methodology}

The methodology in this study that is begun with site response analysis. Then, it is followed by SD calculation and structural drift estimation.

\subsection{Conducting site response analysis}

Equivalent-linear earthquake response analysis model has worked well in most application [13, 14]. Both the time history and sub-surface model were employed for the ground/site response analysis of Banda Aceh, Indonesia. In this study, three historical earthquake events (the 2012 Simeulue II, 2013 Mane-Geumpang, and 2013 Bener Meriah earthquakes) are used in the analysis. One-dimensional (1D) sub-surface models are at Site\#1 (at the eastern of the Banda Aceh city), Site\#2 (at the center of the Banda Aceh), and Site\#3 (at the western of the city). These sub-surface models are based on studies by [15] from which seismic site class D is justified for all these three investigated sites.

\subsection{Calculating displacement response spectra}

In obtaining SD, SA is converted by applying Equation. 1 [4] below.

$$
S D=S A\left(\frac{T}{2 \pi}\right)^{2}
$$

Where:

$\mathrm{T}$ is period (second, $\mathrm{s}$ ),

$\mathrm{SA}$ is spectral acceleration $\left(\mathrm{mm} / \mathrm{s}^{2}\right)$,

$\mathrm{SD}$ is spectral displacement $(\mathrm{mm})$, and $1 \mathrm{~g}=9806.65 \mathrm{~mm} / \mathrm{s}^{2}$.

\subsection{Estimating structural drift}

The building drift is determined from the ratio of displacement with the height of the building. In this study, three different building heights are chosen based on the height of typical shophouse buildings in Banda Aceh which are $8 \mathrm{~m}, 12 \mathrm{~m}$ and $16 \mathrm{~m}$ for 2-, 3-, and 4story shophouse buildings, respectively.

\section{Results and discussion}

As mentioned earlier, three investigated class D seismic sites across the city of Banda Aceh are expected. The SA, SD, and ADRS for class D seismic Site\#1, Site\#2, and Site\#3 are presented in Figures 3 to 5. The most right of each figure shows the relationship between SA and SD which is known as the demand curve. The right and left graphs of the figures reveal that the Proposed SA curves of this study suggest higher than PUSKIM at lower period and displacement. For the middle graphs of the figures show that Site\#1 and Site\#2 had an almost similar trend of displacement versus period both for PUSKIM and Proposed of this study curves. While Site\#3 displays the trend of PUSKIM curve is steeper than the proposed one. No doubt this result is attributed to higher acceleration value of PUSKIM.
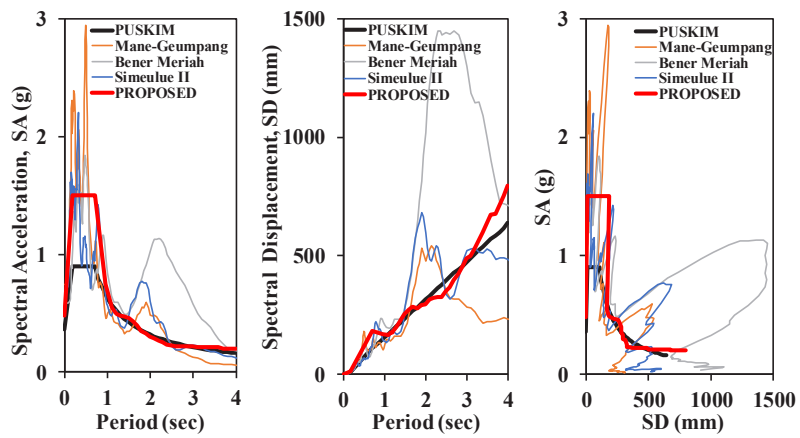

Fig. 3. SA, SD, and ADRS at Site\#1.
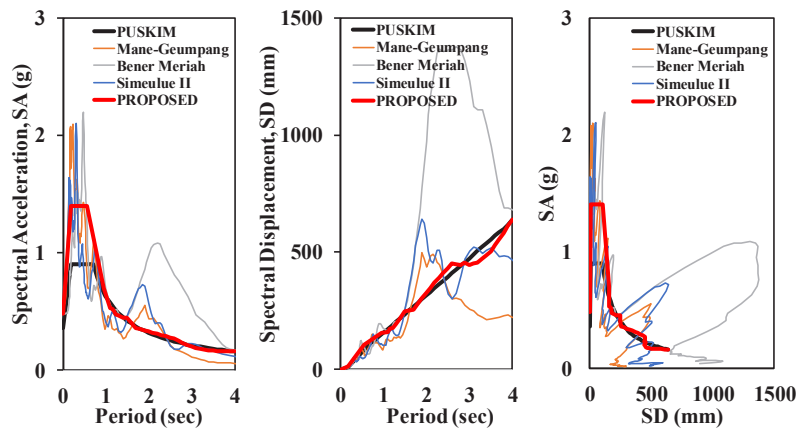

Fig. 4. SA, SD, and ADRS at Site\#2.
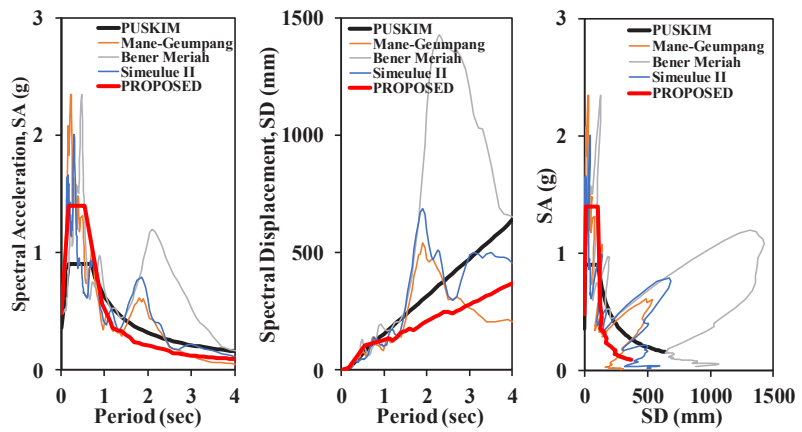

Fig. 5. SA, SD, and ADRS at Site\#3.

The combination of proposed of this study and PUSKIM's ADRS for class D seismic Site\#1, Site\#2, and Site\#3 is presented in Figure 6. The figure reveals that for the period under one second, acceleration and 
displacement for the proposed curve, in general, is greater than PUSKIM. However, for the period greater than one second, only acceleration and displacement at Site\#3 is much less than others.

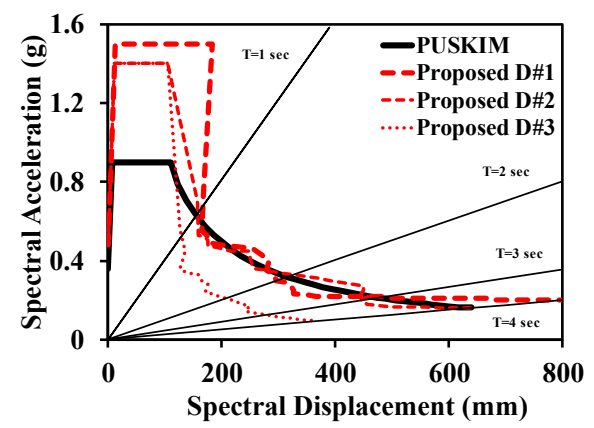

Fig. 6. The comparison of PUSKIM and proposed ADRS class D seismic Site \#1, Site\#2, and Site\#3.

In facilitating the engineers to assess the performance of 2-, 3-, and 4-storey of typical shophouse buildings at the city of Banda Aceh especially at Site\#1, Site\#2, and Site\#3, SA-drift correlations are calculated. Spectral acceleration-drift relationship graphs are presented in Figures 7-9.

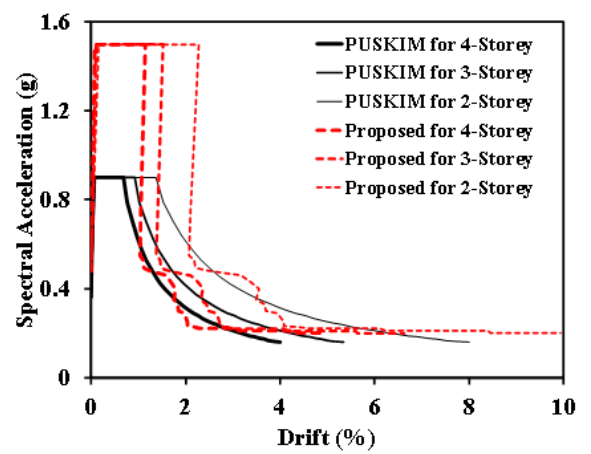

Fig. 7. PUSKIM and proposed spectral acceleration-drift relationship on Site\#1 for different story level.

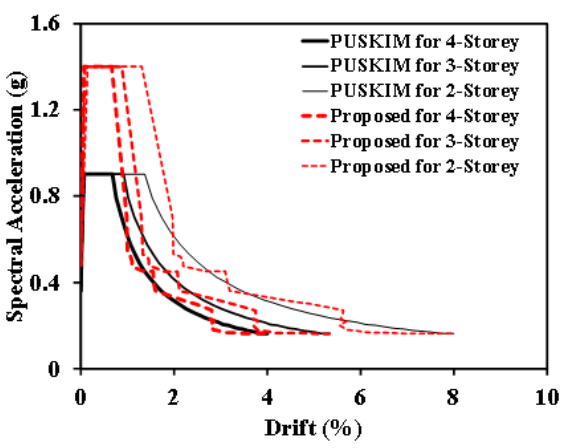

Fig. 8. The proposed spectral acceleration-drift relationship for Site\#2.

Ref. [16] investigated the relationship between building's drift and damage due to an earthquake, as presented in Table 1. This relationship can be used to deduce the building performance at the investigated sites.
If performance level of "life safe-damage state" (drift $<1.5 \%$ ) for 3 -story shophouse building is chosen to apply in Figures 7-9; generally, they show that the proposed SA of this study has high acceleration, as mentioned earlier. This performance indicates that so much earthquake energy is released at smaller drift. Therefore, the capacity of the building should be designed to have high acceleration at small drift.

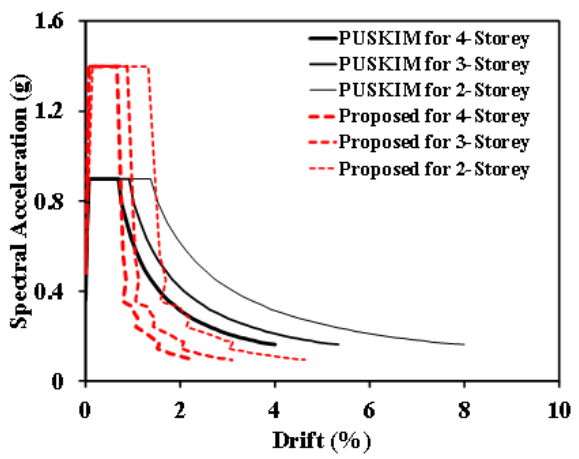

Fig. 9. The proposed spectral acceleration-drift relationship for Site\#3.

Table 1. Performance level, damage state, and drift [17].

\begin{tabular}{|c|c|c|}
\hline Performance level & Damage state & Drift \\
\hline $\begin{array}{c}\text { Fully operational, } \\
\text { immediate occupancy }\end{array}$ & No damage & $<0.2 \%$ \\
\hline $\begin{array}{c}\text { Operational, damage } \\
\text { control, moderate }\end{array}$ & Repairable & $<0.5 \%$ \\
\hline Life safe-damage state & Irreparable & $<1.5 \%$ \\
\hline $\begin{array}{c}\text { Near collapse, limited } \\
\text { safety, hazard reduced }\end{array}$ & Severe & $<2.5 \%$ \\
\hline Collapse & - & $>2.5 \%$ \\
\hline
\end{tabular}

In general, the proposed ADRS of this study is overestimated the PUSKIM's ADRS. This overestimation could be subjected to the different adopted approach or used model in the analysis. Further investigations are necessary to carry out by refining the shear velocity profile of the investigated sites. A simple and affordable method as shown in [17] can be used for this refinement. Furthermore, local site effect, which is confirmed to cause devastating structural damages [1821], must be warranted.

\section{Conclusions}

Recently, performance-based engineering method has rapidly grown as tools in designing new buildings or assessing the existing buildings. This method requires a sensible acceleration-displacement response spectrum (ADRS) on each site where the performance of a building designed or assessed is laid. This study presents the proposed ADRSs for three class D seismic sites across the city of Banda Aceh-Indonesia in comparison to the PUSKIM's ADRS. The proposed ADRSs are obtained from three recent historical earthquakes which are the 2012 Simeulue II, the 2013 Mane-Geumpang, 
and the 2013 Bener Meriah earthquakes. It can be concluded that the proposed ADRSs can be used as another source in determining the performance of a building beside the PUSKIM's ADRSs.

The authors wish to acknowledge the Syiah Kuala University for providing a research funding (Contract No. 88/UN11.2/PP/PNBP/SP3/2018). In addition, the first author is grateful to the Faculty of Engineering of Syiah Kuala University for their support.

\section{References}

1. M. Petersen, J. Dewey, S. Hartzell, C. Mueller, S. Hansen, A. Frankel, K. Rukstales, "Probabilistic seismic hazard analysis for Sumatra, Indonesia and across the southern Malaysian peninsula," Tectonophysics, 390, 141-158 (2001)

2. M. Saatcioglu, A. Ghobarah, L. Nistor, "Performance of structures in Indonesia during the December 2004 great Sumatra earthquake and Indian Ocean tsunami," Earthq. Spectra, 22 (S3), 295-319 (2006)

3. B. Setiawan, T. Saidi, "A preliminary results of sitespecific ground response analysis of Banda Aceh, Indonesia," The Proc. 2nd Annual International Conference Syiah Kuala University 2012 \& 8th IMT-GT Uninet Biosciences Conference Banda Aceh, 22-24 November 2012, 8, (2012)

4. Applied Technology Council, ATC-40 Seismic Evaluation and Retrofit of Concrete Buildings Volume 1 (California: California Seismic Safety Commission, 1996).

5. C.-M. Chan, X.-K. Zou, "Elastic and inelastic drift performance optimization for reinforced concrete buildings under earthquake loads," Earthq. Eng. Struct. Dyn. 33 (8), 929-950 (2004)

6. J.P. Conte, Y. Zhang, "Performance Based Earthquake Engineering: Application to an Actual Bridge-Foundation-Ground System," 12th Italian National Conf. on Earthquake Eng., Pisa, Italy, June 10-14, 2007, 18, (2007)

7. V. Beck, "Performance-based Fire Engineering Design and its Application in Australia. Proceedings of the Fifth International Symposium on Fire Safety Science," World Congress Centre, Melbourne, Australia, 23 - 40 (1997)

8. Federal Emergency Management Agency (FEMA), "Action plan for performance based seismic design," FEMA-349, 81, (2000)

9. S. Sugiarto, T. Miwa, H. Sato, T. Morikawa, "Explaining differences in acceptance determinants towards congestion charging policies in Indonesia and Japan,” J. Urban Plan. Dev. 143 (2), 1-12 (2016)

10. S. Sugiarto, T. Miwa, T. Morikawa, "Inclusion of latent constructs in utilitarian resource allocation model for analyzing revenue spending options in congestion charging policy," Transp. Res. Part A: Policy \& Practice, 103, 36-53 (2017)
11. S. Sugiarto, T. Miwa, T. Morikawa, "Recursive bivariate response models of the ex-ante intentions to link perceived acceptability among charge and refund options for alternative road pricing schemes," Transp. Lett. 10 (1), 52-63 (2018)

12. PPMB-ITB. Desain Spektra Indonesia 2011. Pusat Penelitian dan Pengembangan Perumahan dan Permukiman (PUSKIM) Kementerian Pekerjaan Umum, 2011. [Online]. Available: http://puskim.pu.go.id/Aplikasi/desain_spektra_indo nesia_2011/. [Accessed: 02-Feb-2018], (2018)

13. P. Schnabel, J. Lysmer, H. Seed, A computer program for earthquake response analysis of horizontally layered sites, Earthquake Engineering Research Center EERC Report 72-12. Berkeley, California: University of California, (1972)

14. B. Setiawan, "Site Specific Ground Response Analysis for Quantifying Site Amplification at A Regolith Site," Indones. J. Geosci. 4 (3), 159-167 (2017)

15. U. Polom, I. Arsyad, H. Kumpel, "Shallow shearwave reflection seismics in the tsunami struck Krueng Aceh River Basin, Sumatra," Adv. Geosci. 14, 135-140 (2008)

16. A. Ghobarah, "Performance-based design in earthquake engineering: state of development," Eng. Struct., 23(8, 878-884 (2001)

17. B. Setiawan, M. Jaksa, M. Griffith, D. Love, "Seismic site classification based on constrained modeling of measured HVSR curve in regolith sites," Soil Dyn. Earthq. Eng. 110, 244-261 (2018)

18. E.D. Booth, J.W. Pappin, J.H. Mills, M.R. Degg, R.S. Steedman, The Mexican earthquake of 19th September 1985. Earthquake Eng. Field Invest. Team (EEFIT), Soc. Earthquakes Civ. Eng. Dyn., London, U.K., 146 pp., (1986)

19. C.A. Brebbia (Ed). The Kobe earthquake: geodynamical aspects. Comput. Mech. Publ., Southampton, U.K., 145 pp., (1996)

20. D. Bindi, R.R. Castro, G. Franceschina, L. Luzi, F. Pacor, "The 1997-1998 Umbria- Marche sequence (central Italy): source, path and site effects estimated from strong motion data recorded in the epicentral area," J. Geophys. Res. 109, B04312 (2004)

21. B. Setiawan, M. Jaksa, M. Griffith, D. Love, “An investigation of local site effects in Adelaide, South Australia: learning from the past," Boll. Geof. Teor. Appl. 59 (1), 27-46 (2018) 